\title{
Firing up for Earth summit
}

\section{São Paulo}

BRAZIL's environmental secretary, José Lutzenberger, was fired last weekend as the government moved to end an internal dispute that officials fear could damage the forthcoming Earth Summit in Rio de Janeiro. Lutzenberger has been replaced by José Goldemberg, a physicist who is already Minister of Education and, now, certainly the most politically powerful scientist in the recent history of Brazil.

Lutzenberger was dismissed by President Fernando Collor de Mello after making derogatory comments about the government's ability to carry out environmental reforms. Last month, at meetings in New York to prepare for the June summit, Lutzenberger praised a decision by the G-7 states to reduce by one-sixth their scientific and environmental aid to Amazonia because, Lutzenberger said, he feared that a corrupt Brazilian government would squander the original US $\$ 1,500$ million that had been pledged. And he questioned the integrity of one of the agencies within his ministry, the Institute of the Environment and Natural Renewable Resources (IBAMA). Collor also fired the president of the institute, biologist Eduardo Martins.

The institute has been in turmoil for the past year. Martins had been appointed by Lutzenberger last autumn after the previous head, Tania Munhoz, became embroiled in a battle with Lutzenberger over his style of leadership. Martins offered to resign after being criticized by Lutzenberger, but Lutzenberger refused to accept the resignation. Martins, a primate specialist, says that he is "returning to the monkeys".

Lutzenberger is an agronomist who is allied with the radical environmental move- ment in Brazil. Since his appointment two years ago he has been in a running battle with those who advocate rapid development of the country's natural resources. His statement last month that the environmental institute was in league with the timber industry reflects the tension between his views and those of Collor's government, which is promoting a policy of "sustainable development".

Goldemberg, who has strong ties to the international scientific community, is also viewed as a savvy politician. He was appointed secretary of science and technology shortly after Collor took office two years ago, and left his deputy in charge when he moved to the education ministry. For a short time this year he also served as Minister of Health after Collor sacked the minister for alleged financial improprieties. Goldemberg will remain as head of both ministries at least through the Earth Summit in June.

Lutzenberger, on the other hand, has shown little aptitude either for management or compromise. Even his friends admit that he has been something of a loose cannon at political gatherings, and they are unhappy that he has ignored remote sensing data showing the increasing deforestation of the Amazon in making the case for environmental preservation to Collor and his fellow Cabinet officials.

Goldemberg has promised to collect the money already pledged to environmental projects in Brazil. Brazil is paying fines on US $\$ 167$ million lent by the World Bank, and none of the $\$ 250$ million approved by the G-7 group has reached the country. In the past, Goldemberg has demonstrated good relations with such international lending bodies.

Ricardo Bonalume

\section{UK UNIVERSITIES}

\section{Better luck second time?}

\section{London}

HAVING weathered a storm of criticism in its first attempt to rank UK universities by the quality of their research, the University Funding Council (UFC) is taking a different approach the second time around.

Rather than using a anonymous peerreview team to evaluate all department members at each university, as it did five years ago, the UFC will examine only the work of active researchers. Only a researcher's two most significant recent papers will be reviewed and ranked according to the quality of the journal in which it is published. The UFC also plans to name the members of the review committees, who will be appointed next month and will start their evaluations in June. More than 150 institutions of higher education will be reviewed, and the resulting rankings will form the basis for UK research funding in 1993 and 1994.

The Committee of Vice-Chancellors and Principals and the Committee of Directors of Polytechnics say they are satisfied that the new system of ranking is fair. But the Association of University Teachers is concerned that the general policy of rewarding the past will make it harder for up-and-coming institutes to get their foot on the funding ladder. They say that the system also encourages a separation of research-based departments and teachingbased departments, which runs counter to the traditional view that teaching is carried out most effectively in an atmosphere of research.

Alison Abbott

\section{Budgets cut again}

\section{Cape Town}

While South Africa rejoiced in last Wednesday's referendum vote in support of an end to white minority rule, the budget, announced the same day, offered little cheer to the research community. Although government expenditure rose by 16 per cent (roughly in line with inflation), the science budget, divided between the five statutory councils, fell by 3.6 per cent.

The annual reductions are the second in succession for South African researchers, who last year saw cuts in the budgets of four of the five councils for the first time in recent memory despite an overall increase in government spending. And the figures are especially disappointing to those whose hopes were raised last autumn by comments from the Minister of National Education, Louis Pienaar, who warned against the perils of cutting science funding in a speech to the Science Advisory Council. Pienaar heads the department through which research funds are channelled.

Most of the large increase ( 24 per cent) in education funding was awarded to the Department of Education and Training, which is responsible for black schools. Even so, universities fared slightly better than the research councils, receiving increases in their subsidies of $\mathbf{1 . 6}$ per cent.

All of the five research councils funded through the science vote received cuts in their parliamentary grants. The 1992-93 allocations to the councils were as follows: the Council for Scientific and Industrial Research (CSIR), US\$69.7 million, down 5.4 per cent; the Foundation for Research Development, \$34.9 million, down 3.5 per cent; the Human Sciences Research Council, $\$ 23.7$ million, down 0.5 per cent; the Council for Mineral Technology (Mintek), $\$ 18$ million, down 1.3 per cent; and the Medical Research Council, $\$ 13.4$ million, down 2.3 per cent.

In addition, the new Agricultural Research Council (ARC), which will become the country's sixth statutory council on 1 April, received a parliamentary grant of $\$ 78.6$ million. The new council will comprise ten research institutes, two research centres and one directorate currently falling under the Department of Agricultural Development.

The department's incumbent president, Alec Heyns, says that the creation of a statutory council will give its administrators greater freedom to hire scientists and assign them to specific projects. Unlike departments, councils may also solicit funds from the private sector.

But some scientists are sceptical about the value of the new council. "The play has been changed, but many of the actors are the same", says Roy Siegfried, director of the Percy Fitzpatrick Institute of African Ornithology at the University of Cape Town. Michael Cherry 